\title{
DENDROFLORA OF CALCAREOUS TERRAINS IN BULGARIA AND ITS SIGNIFICANCE FOR CONSERVATION
}

\author{
Alexander N. Tashev, Evgeni I. Tsavkov \\ University of Forestry, Bulgaria \\ e-mail: atashev@mail.bg;tsavkov@abv.bg
}

Received: 5.10.2016

\begin{abstract}
The work presents characteristics of calciphile species from the dendroflora of Bulgaria (107 species), both facultative (77 species) and obligated (30 species) - their systematic structure according to families and genera, division according to biological types and live forms, as well as floristic geo-elements and spreading on vertical belts and floristic regions in Bulgaria. The conservation significance of calciphiles at national and international level has been shown on the basis of referent documents. A systematic list of calciphile species of the Bulgarian dendroflora has been presented.
\end{abstract}

Key words: Bulgaria, calcareous terrains, conservation significance, dendroflora.

Calcareous terrains are associated with the distribution of a specific flora and vegetation with southern peculiarities and an endemic character. Limestone in Bulgaria covers significant areas - 22.7\% of the country (Georgiev \& Mihailov, 1977) (Fig. 1, 5). As a result of analysing literature sources (Jordanov, 1963-1979; Ellenberg, 1974; Georgiev \& Mihailov 1977; Velchev, 1982; 1985; Kozhuharov, 1995; Velchev, 1998; Uzunov \& Gus- sev, 2003; Delipavlov \& Cheshmedzhiev, 2011; Kozhuharov \& Anchev, 2012; Assyov \& Petrova, 2012) and data from own investigations (Kalinkov et al., 1991; Tashev \& Borisova, 2005; Tashev \& Angelova, 2006; Tashev \& Alexandrova, 2009; Tashev, Tsavkov \& Koev, 2013a,b; Tashev A.N., Koev \& Tashev N.A., 2013a,b), a list of calciphile species of dendroflora has been compiled here for the first time for Bulgaria.

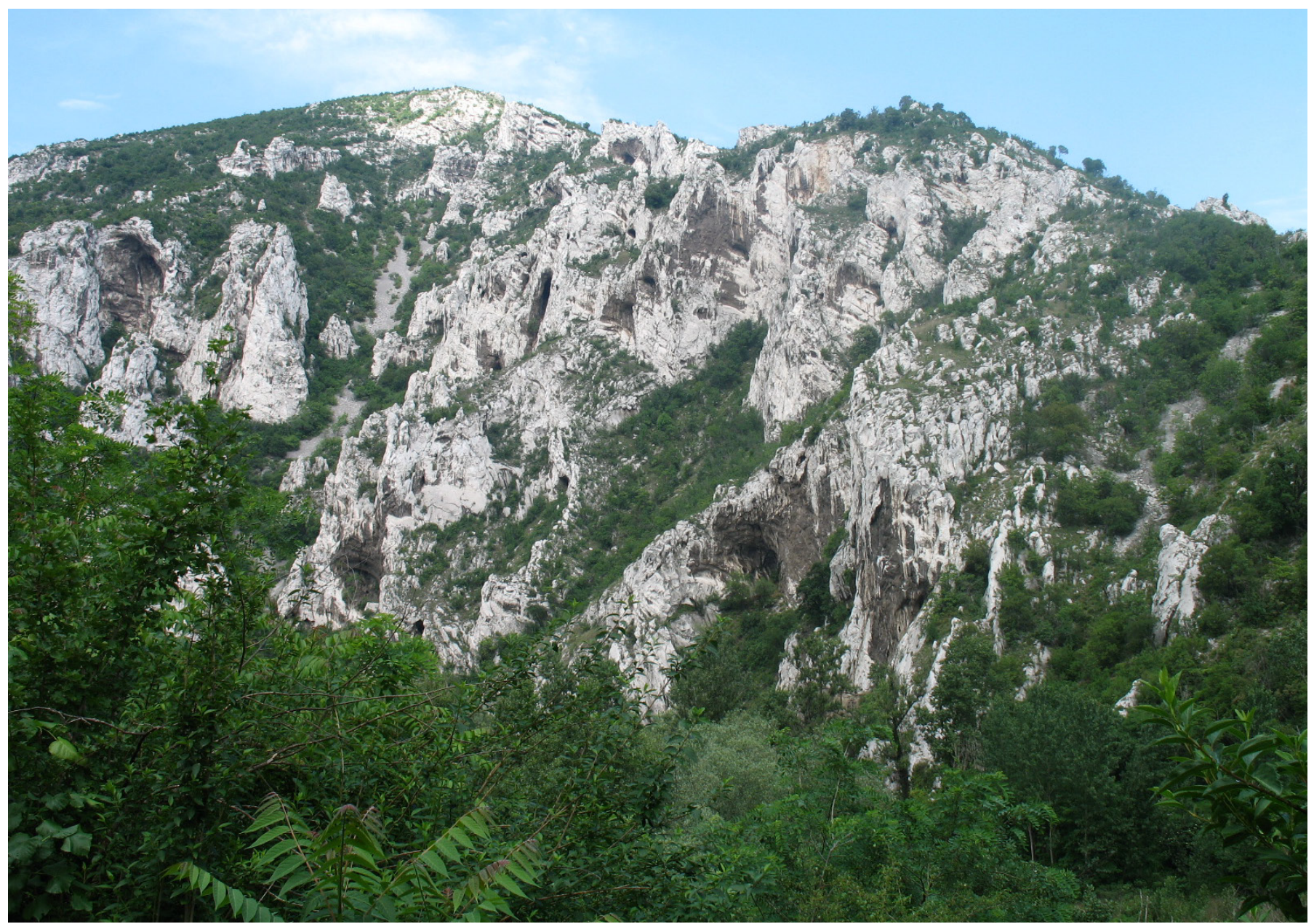

Fig. 1. Typical calcareous habitat in Western Balkan Range (Nature Park Vrachansky Balkan). 
When compiling the list, all species were divided into 2 groups: 1) obligate calciphiles (o) or species known only in calcareous habitats in the country; 2) facultative calciphiles (f) or species known mostly from limestones (Velchev, 1998). The list contains 107 species belonging to 57 genera and 27 families (Table 1). Of them, 30 species are classified as obligate calciphiles, and 77 species as facultative calciphiles. This amounts $24.8 \%$ of the species, $38.5 \%$ of the genera and $45.0 \%$ of the families of the Bulgarian dendroflora, as well as $26 \%$ of the species, $6.2 \%$ of the genera and $17.4 \%$ of the families of the whole Bulgarian flora. The Pinophyta include six species belonging to two genera and two families, while the Magnoliophyta include 101 species belonging to 55 genera and 25 families. Amongst the families, the Fabaceae is represented by 23 species, followed by Rosaceae - 22 species, Lamiaceae - 11 species, Rhamnaceae -6 species, Brassicaceae, Salicaceae, Cupressaceae and Thymeleaceae -4 species each, Oleaceae and Cistaceae - 3 species each, Betulaceae, Pinaceae, Cornaceae, Anacardiaceae, Aceraceae and Rutaceae - 2 species each. Eleven families include one species each. Amongst the genera, Chamaecytisus is represented by the highest number (7) of species, followed by Rosa and Genista - 6 species each, Sorbus and Satureja - 5 species each, Daphne, Salix, Rhamnus, Thymus and Juniperus -4 species each, Corothamnus -3 species, Rhodax, Cornus, Mattiola, Crataegus, Pinus, Iberis, Prunus, Cotoneaster and Acer -2 species each. The other 35 genera are represented by one species each.

Biological types are distributed as follows: 58 species - shrubs (54\%), 17 species - shrubs or trees $(16 \%)$; trees are 10 species (9\%), 6 species are semishrubs $(6 \%)$ and transitional group (perennial herbs to semi-shrubs) include 16 species (15\%) (Fig. 2).

According to the classification of life forms after Raunkiaer (1934) phanerophytes $(\mathrm{Ph})$ are represented by 72 species, chamaephytes $(\mathrm{Ch})$ by 13 ; other species may move from one group to another, including 15 species, which could be hemicryptophytes $(\mathrm{H})$ (i.e. perennial herbs) under certain conditions (Table 2).

Amongst the geo-elements of the flora, presented according to the Walter system, which is adapted in the flora of Bulgaria (Assyov \& Petrova, 2012), the majority of species are with a Mediterranean component $(M e d)$ - 61 species, including 30 sub-Mediterranean (subMed) species. Balkan endemics (Bal) include 12 species (Aesculus hippocastanum, Astracantha thracica, Chamaecytisus calcareus, Ch. jankae, Corothamnus agnipilus, C. rectipilosus, Genista rumelica, G. subcapitata, Rhamnus rhodopaeus, Satureja pilosa, Thymus longedentatus, Viola delphinantha), Bulgarian endemics $(B u l)$ are represented by four species (Chamaecytisus kovacevii, Satureja rumelica, Thymus perinicus, Veronica kellererii). Other groups are poorly presented.
According to the classification of phytogeographic elements after B. Stefanoff (1943) stationary and mobile thermophytes, mesotherms, microtherms from Mountainous Centre predominate -75 species, followed by stationary thermophytes from the Mediterranean Centre -14 species, stationary and mobile mesotherms from the Sylvic-Boreal Centre ( 8 species), stationary and movable thermophytes from the Northern Continental Centre (area of the South Russian Plain) - 6 species, and stationary and movable thermophytes from the Southern Continental Centre - 4 species. Moreover, from the 107 species, 99 (92.5\%) are stationary plants, and only eight species are movable plants having a wider range of ecological niche. There are neither secondary nor alien species within the studied group of arboreal plants. This proves their strong confinement to the calcareous rocks.

Depending on the vertical distribution in the country, plant species living within an altitudinal belt from 0 to $600 \mathrm{~m}$ above sea level predominate (82 species), followed by the altitudinal belt 600 $1000 \mathrm{~m}$ a.s.1. -77 species, $1000-1500 \mathrm{~m}$ a.s.1. -66 species, $1500-2000 \mathrm{~m}$ a.s.1. -36 species, 2000-2500 $\mathrm{m}$ a.s.l. -19 species. Only nine species are known within the altitudinal belt from 2500 to $2900 \mathrm{~m}$ a.s.1. Fig. 3 (blue line) represents the relationship between the vertical distribution of the calcareous dendroflora along altitudinal belts. The empirical relationship is $\mathbf{y}=\mathbf{- 1 6 . 2 5 7 x}+\mathbf{1 0 5 . 0 7}$, where $\mathbf{y}$ is the number of species, and $\mathbf{x}$ is the altitudinal belt. The regression coefficient is $\mathbf{R}^{\mathbf{2}}=\mathbf{0 . 9 5 8 2}$.

Amongst the 20 floristic regions of Bulgaria (Fig. 4 ), the highest number of calciphile species has been registered in the Rhodopes ( 81 species $-75.7 \%$ of the total number of calciphile species in Bulgaria's dendroflora), followed by 77 species $(72.0 \%)$ in Stara Planina Mt. (Balkan Range) (Fig. 1.), 63 species (58.9\%) in Pirin Mt. (Fig. 5.), 56 species - in Slavianka Mt., Znepole region - 55 species, Thracian Plain - 53 species, Rila Mt. - 51 species, the Black Sea coast - 49 species, North-Eastern Bulgaria and Fore-Balkan region -47 species each, the Tundzha Hilly Plain - 46 species, Vitosha region - 45 species, the Struma valley and Sredna Gora Mt. -41 species each, the Danubian Plain - 40 species, West Frontier Mountains - 39 species, Strandzha Mt. - 35 species, Belasitsa Mt. and the Mesta River Valley - 33 species each, and the smallest species number (31) is found in the region Sofia. There are 9 species registered only in one certain floristic region, 12 species - only in two certain regions, 5 species are specific for three floristic regions, 11 species - for 4 regions, 8 species - for five floristic regions, etc. There are 20 calciphile species of Bulgaria's dendroflora which are known in all 20 floristic regions. 
Table 1. Systematic list of dendroflora of calcareous terrains in Bulgaria («o» - obligate calciphiles, «f» facultative calciphiles)

\begin{tabular}{|c|c|c|}
\hline Higher taxa & Family & Species \\
\hline \multirow[t]{2}{*}{ Pinophyta } & Cupressaceae & $\begin{array}{l}\text { Juniperus deltoides R.P. Adams (f); J. excelsa M. Bieb. (f); J. sabina L. (f); J. sibirica } \\
\text { Burgsd. (J. communis subsp. nana (Willd.) Syme) (f) }\end{array}$ \\
\hline & Pinaceae & Pinus heldreichii H. Christ (o); P. nigra J.F. Arnold (f) \\
\hline \multirow{25}{*}{$\begin{array}{l}\text { Magnoliophyta } \\
\text { (Magnoliopsida) }\end{array}$} & Aceraceae & Acer monspessulanum L. (f); A. tataricum L. (f) \\
\hline & Anacardiaceae & Cotinus coggygria Scop. (o); Pistacia terebinthus L. (f) \\
\hline & Betulaceae & Carpinus orientalis Mill. (f); Ostrya carpinifolia Scop. (f) \\
\hline & Brassicaceae & $\begin{array}{l}\text { Iberis saxatilis L. (o); I. sempervirens L. (f); Matthiola fruticulosa (L.) Maire (f); } M \text {. } \\
\text { odoratissima (M. Bieb.) R. Br. (f) }\end{array}$ \\
\hline & Caprifoliaceae & Viburnum lantana L. (f) \\
\hline & Celastraceae & Euonymus verrucosus Scop. (f) \\
\hline & Chenopodiaceae & Kochia prostrata (L.) Schrad. (f) \\
\hline & Cistaceae & Fumana procumbens Gren. \& Godr. (f); Rhodax alpestris Fuss (o); R. canus Fuss (o) \\
\hline & Convolvulaceae & Convolvulus boissieri Steud. (o) \\
\hline & Cornaceae & Cornus mas L. (f); C. sanguinea L. (f) \\
\hline & Fabaceae & $\begin{array}{l}\text { Astracantha thracica (Griseb.) Podlech (f); Astragalus angustifolius Lam. (o); Caragana } \\
\text { frutex (L.) K. Koch (o); Cercis siliquastrum L. (f); Chamaecytisus calcareus (Velen.) } \\
\text { Kuzmanov (o); C. ciliatus (Wahlenb.) Rothm. (o); C. danubialis (Velen.) Rothm. (f); C. } \\
\text { glaber (L.f.) Rothm. (f); C. jankae (Velen.) Rothm. (f); C. kovacevii (Velen.) Rothm. (f); } \\
\text { C. pygmaeus (Willd.) Rothm. (f); Colutea arborescens L. (f); Coronilla emerus L. (o); } \\
\text { Corothamnus agnipilus (Velen.) Klбsk. (f); C. procumbens C. Presl (f); C. rectipilosus } \\
\text { (Adamow) Skalick6 (f); Genista anatolica Boiss. (f); G. depressa M. Bieb. (f); G. } \\
\text { januensis Viv. (f); G. rumelica Velen. (f); G. sessilifolia DC. (o); G. subcapitata Panuiж } \\
\text { (f); Lembotropis nigricans (L.) Griseb. (f) }\end{array}$ \\
\hline & Fagaceae & Quercus pubescens Willd. (f) \\
\hline & Globulariaceae & Globularia cordifolia L. (o) \\
\hline & Hippocastanaceae & Aesculus hippocastanum L. (o) \\
\hline & Lamiaceae & $\begin{array}{l}\text { Hyssopus officinalis L. (o); Salvia tomentosa Mill. (f); Satureja coerulea Janka } \\
\text { (o); S. cuneifolia Ten. (f); S. montana L. (f); S. pilosa Velen. (f); S. rumelica Velen. } \\
\text { (o); Thymus leucotrichus Halocsy (o); T. longedentatus Ronniger (o); T. perinicus } \\
\text { (Velen.) Jalas (o); T. zygioides Griseb. (f) }\end{array}$ \\
\hline & Loranthaceae & Arceuthobium oxycedri M. Bieb. (f) \\
\hline & Oleaceae & Fraxinus ornus L. (f); Ligustrum vulgare L. (f); Syringa vulgaris L. (f) \\
\hline & Rhamnaceae & $\begin{array}{l}\text { Frangula rupestris Schur (f); Paliurus spina-christi Mill. (f); Rhamnus alpina L. (f); } \\
R \text {. cathartica L. (f); R. rhodopea Velen. (f); R. saxatilis Jacq. (o) }\end{array}$ \\
\hline & Rosaceae & $\begin{array}{l}\text { Amelanchier ovalis Medik. (f); Amygdalus nana L. (f); Cotoneaster nebrodensis K. } \\
\text { Koch (o); C. niger (Wahlb.) Fr. (f); Crataegus monogyna Jacq. (f); C. pentagyna } \\
\text { Waldst. \& Kit. ex Willd. (f); Dryas octopetala L. (f); Prunus fruticosa Pall. (f); } \\
\text { P. mahaleb L. (f); Pyrus pyraster (L.) Burgsd. (f); Rosa heckeliana Tratt. (o); R. } \\
\text { micrantha Borrer (f); R. obtusifolia Desv. (f); R. pimpinellifolia L. (R. spinosissima } \\
\text { L.) (f); R. pulverulenta M. Bieb. (o); R. turcica Rouy (f); Rubus saxatilis L. (f); } \\
\text { Sorbus austriaca Hedl. (f); S. chamaemespilus Crantz (f); S. domestica L. (f); S. } \\
\text { graeca (Spach) Lodd. ex S.Schauer (o); S. torminalis (L.) Crantz (f) }\end{array}$ \\
\hline & Rutaceae & Dictamnus albus L. (f); Ruta graveolens L. (o) \\
\hline & Salicaceae & Salix eleagnos Scop. (f); S. hastata L. (o); S. purpurea L. (f); S. reticulata L. (f) \\
\hline & Saxifragaceae & Ribes alpinum L. (f) \\
\hline & Scrophulariaceae & Veronica kellererii Degen \& Urum. (o) \\
\hline & Thymeleaceae & $\begin{array}{l}\text { Daphne blagayana Freyer (f); D. cneorum L. (f); D. laureola L. (o); D. oleoides } \\
\text { Schreb. (f) }\end{array}$ \\
\hline & Violaceae & Viola delphinantha Boiss. (o) \\
\hline
\end{tabular}

The dendroflora of the calcareous terrains has a large significance for nature conservation. The Red Data Book of the Republic of Bulgaria (Peev, 2015) contains data about 13 of the investigated species: Aesculus hippocastanum, Astracantha thracica, Caragana frutex, Chamaecytisus kovacevii, Convolvulus boissieri, Daphne blagayana, D. cneorum, D. laureola, Juniperus sabina, Matthiola odoratissima, Ruta graveolens, Thymus perinicus and Viola delphinantha. Fifteen species are protected by the Biodiversity Act of Bulgaria (2007): Aesculus hippocastanum, Astracantha thracica, Caragana frutex, Chamaecyt- 
isus kovacevii, Convolvulus boissieri, Daphne blagayana, D. cneorum, D. laureola, Juniperus exelsa, J. sabina, Matthiola odoratissima, Rhamnus alpinus, Ruta graveolens, Thymus perinicus and Viola delphinantha. Four species are included in the List of Rare Threatened and Endemic Plants in Europe (Lucas, 1983): Chamaecytisus kovacevii, Hyssopus officinalis, Satureja pilosa and Viola delphinantha. Three species (with category «rare species») are listed in «1997 IUCN Red Lists of Threatened Plants» (Walter \& Gillett, 1998): Chamaecytisus kovacevii, Thymus perinicus and Viola delphinantha. Viola delphinantha is strongly protected by the Bern Convention (1978). Amongst plants of calcareous habitats, there are 26 tertiary relicts, 76 ornamental plants, 74 melliferous plants and 41 medicinal plants.

Obligate calciphiles in the Bulgarian dendroflora are presented by 30 species belonging to 24 genera and 15 families, which represent $6.9 \%$ species, $16.2 \%$ genera and $25.0 \%$ families of the total number of species in the Bulgarian dendroflora. The Pinophyta include one species, while the Magnoliophyta include 29 species, belonging to 23 genera and 15 families. Amongst the families, the Fabaceae and Lamiaceae contain the highest number of species ( 6 species each), followed by Rosaceae (4 species), Cistaceae -2 species. The other 13 families are represented by one species. Amongst the genera, Thymus includes the highest number of species (3), followed by Rosa, Rodax, Chamaecytis- sus and Satureja (2 species each). The other 20 genera contain one species each.

The biological types are distributed as following: 14 species are shrubs, 8 species - semi-shrubs or perennial herbs, 4 species - semi-shrubs, and 3 species - trees. The Phanerophytes $(\mathrm{Ph})$ are represented by 14 species, the Chamaephytes $(\mathrm{Ch})$ - by 7 , the other 8 species may vary from one group to another, including 7 species, which may be hemicryptophytes $(\mathrm{H})$ (i.e. perennial herbs) under certain conditions (Raunkiaer, 1934) (Table 2).

Amongst the geo-elements of the flora presented according to the Walter system, which is adapted by the flora of Bulgaria (Assyov \& Petrova, 2012), the majority of species are also with a Mediterranean component $(\mathrm{Med})-15$ species, including 6 sub-Mediterranean (subMed) species. Balkan endemics $(\mathrm{Bal})$ are represented by 4 species (Aesculus hippocastanum, Chamaecytisus calcareus Thymus longedentatus, Viola delphinantha), and Bulgarian endemics (Bul) - by 2 species (Satureja rumelica, Thymus perinicus, Veronica kellererii). The other groups are poorly presented. According to the classification of phytogeographic elements after B. Stefanoff (1943) stationary thermophytes, mesotherms, microtherms from the Mountainous Centre predominate -23 species, followed by stationary thermophytes from the Mediterranean Centre -4 species.

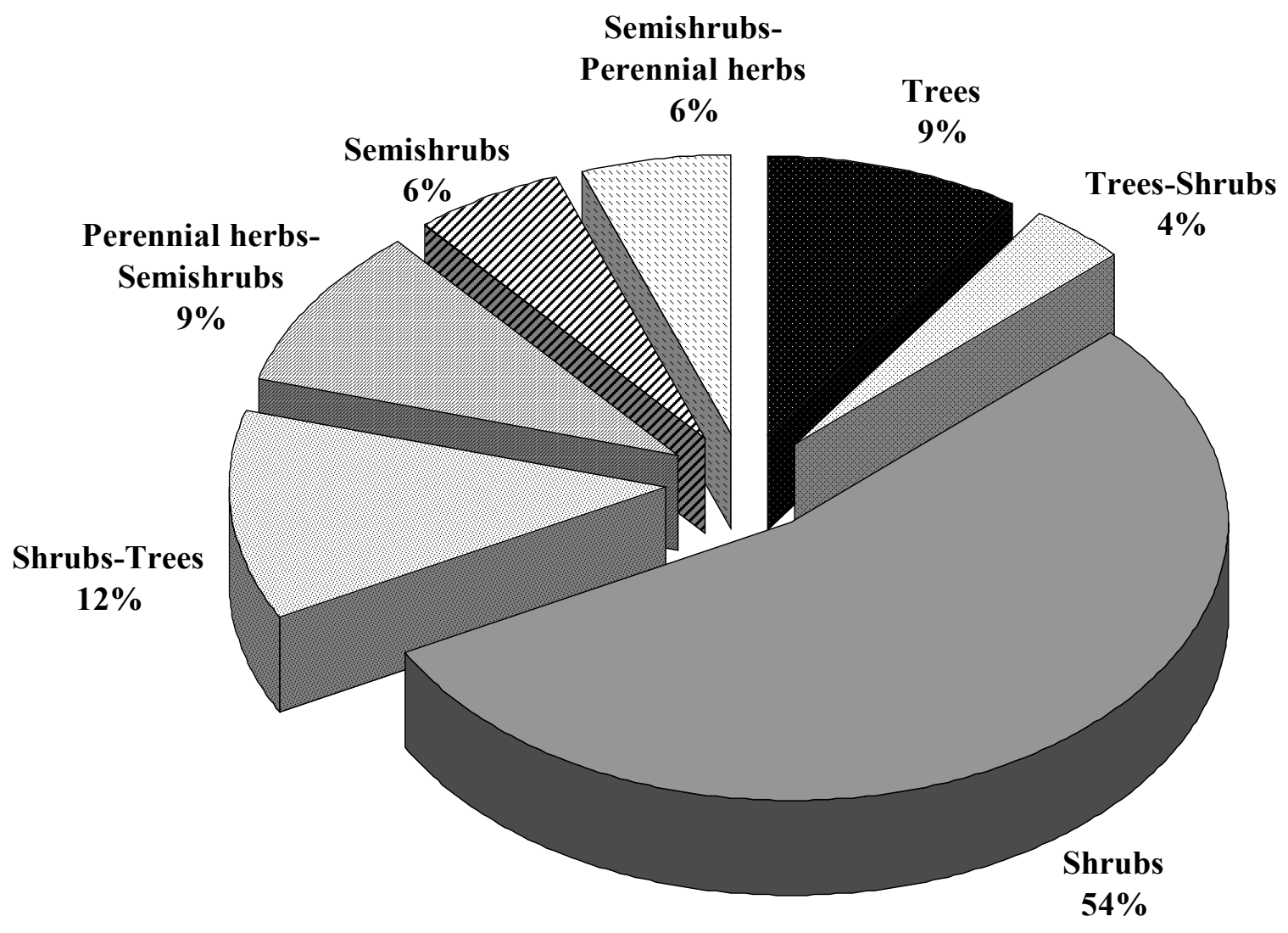

Fig. 2. Distribution of calciphile species of Bulgarian dendroflora according to biological types. 


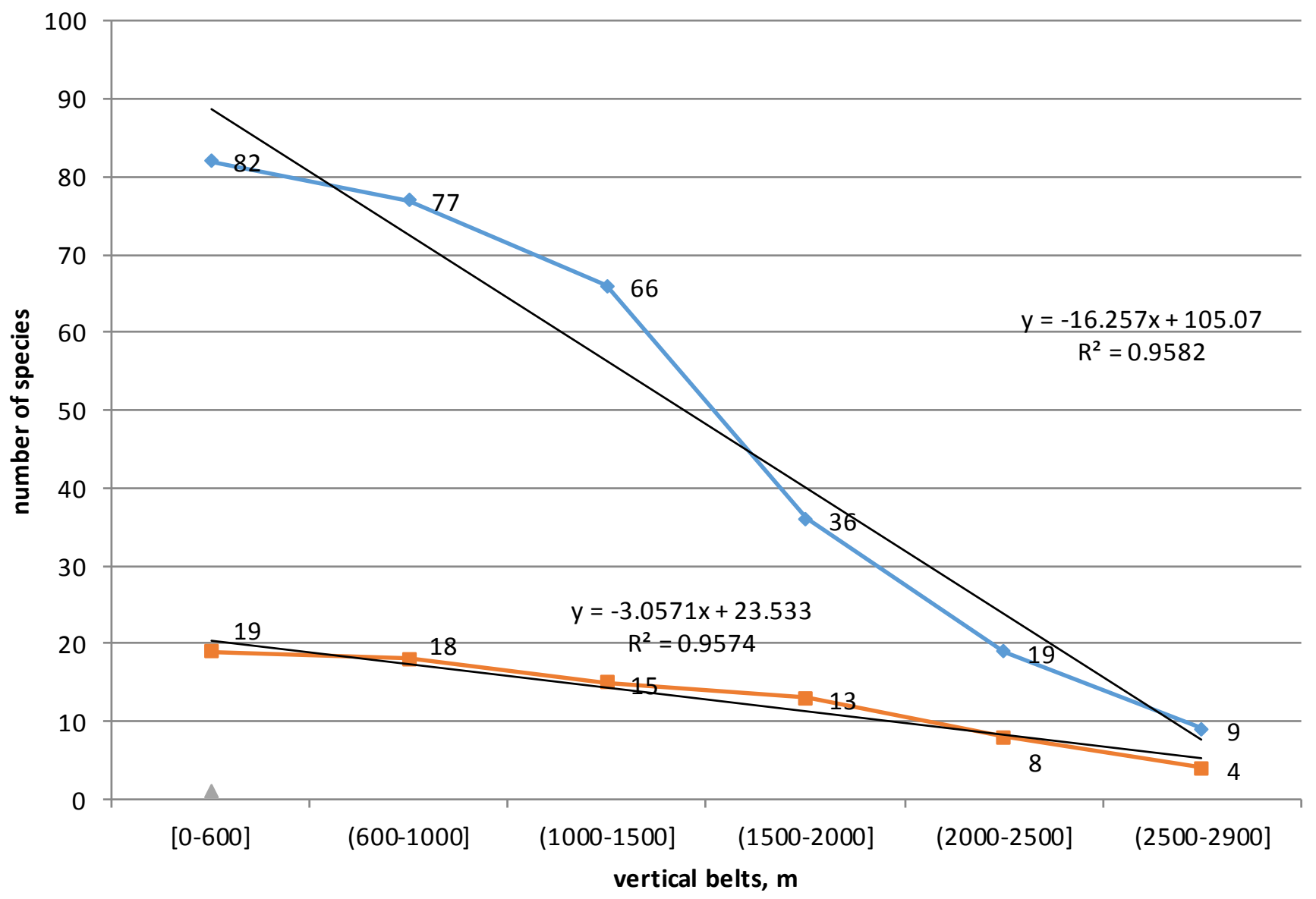

Fig. 3. Distribution of species number of Bulgarian calciophiles dendroflora by vertical belts. Blue line all calciphiles of Bulgarian dendroflora; brown line - obligate calciphiles of Bulgarian dendroflora.

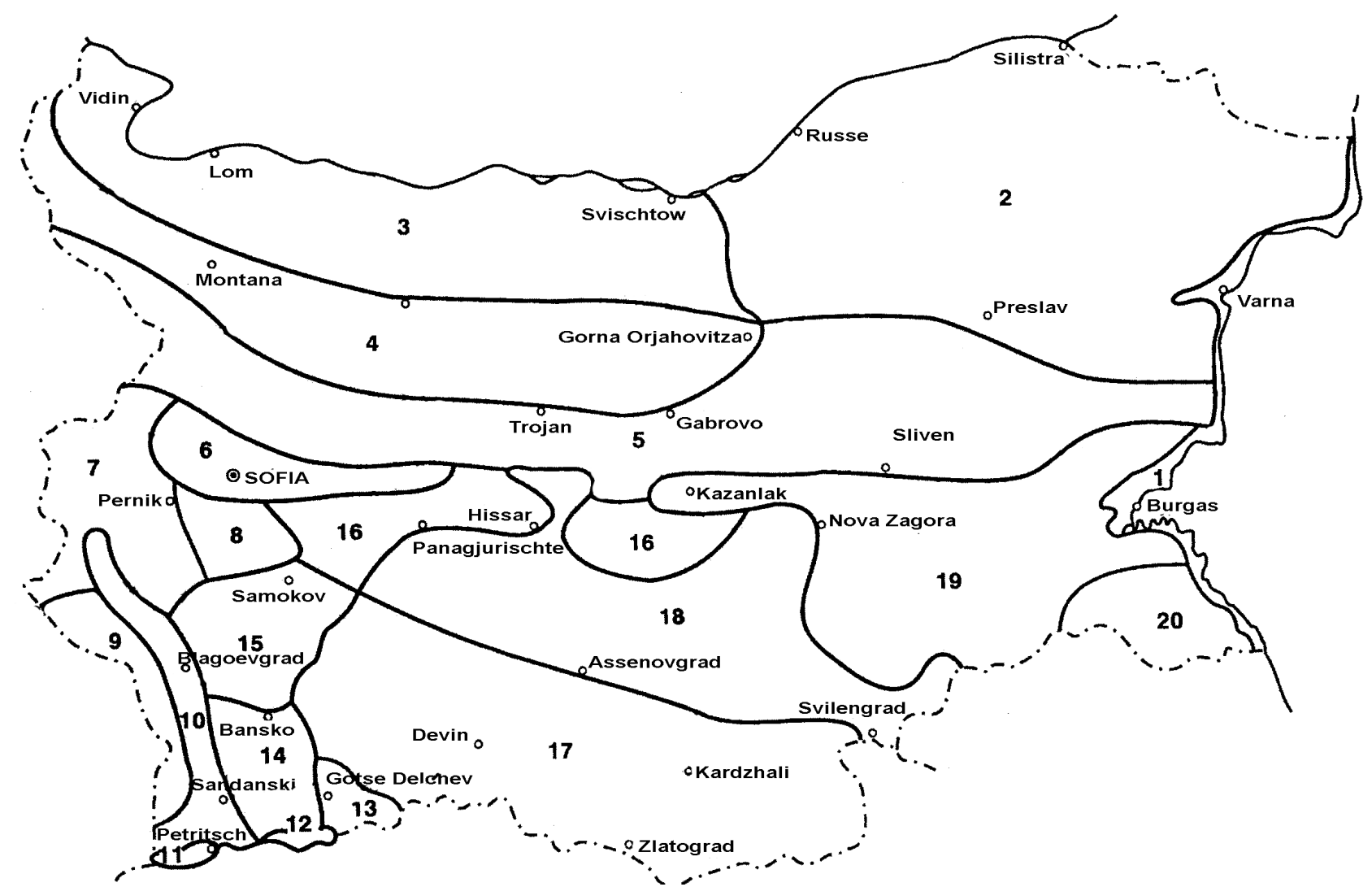

Fig. 4. Floristic regions in Bulgaria (according to Bondev, 1966). Legend: 1. The Black Sea coast; 2. NorthEastern Bulgaria; 3. Danubian Plain; 4. Fore-Balkan; 5. Stara Planina Mt. (Balkan Range) (Fig. 1.); 6. Sofia region; 7. Znepole region; 8. Vitosha region; 9. West Frontier Mountains; 10. Struma River Valley; 11. Belasitsa Mt.; 12. Slavyanka Mt.; 13. Mesta River Valley; 14. Pirin Mt. (Fig. 5.); 15. Rila Mt.; 16. Sredna Gora Mt.; 17. The Rhodopes; 18. Thracian Plain; 19. Tundzha Hilly Plain; 20. Strandzha Mt. 


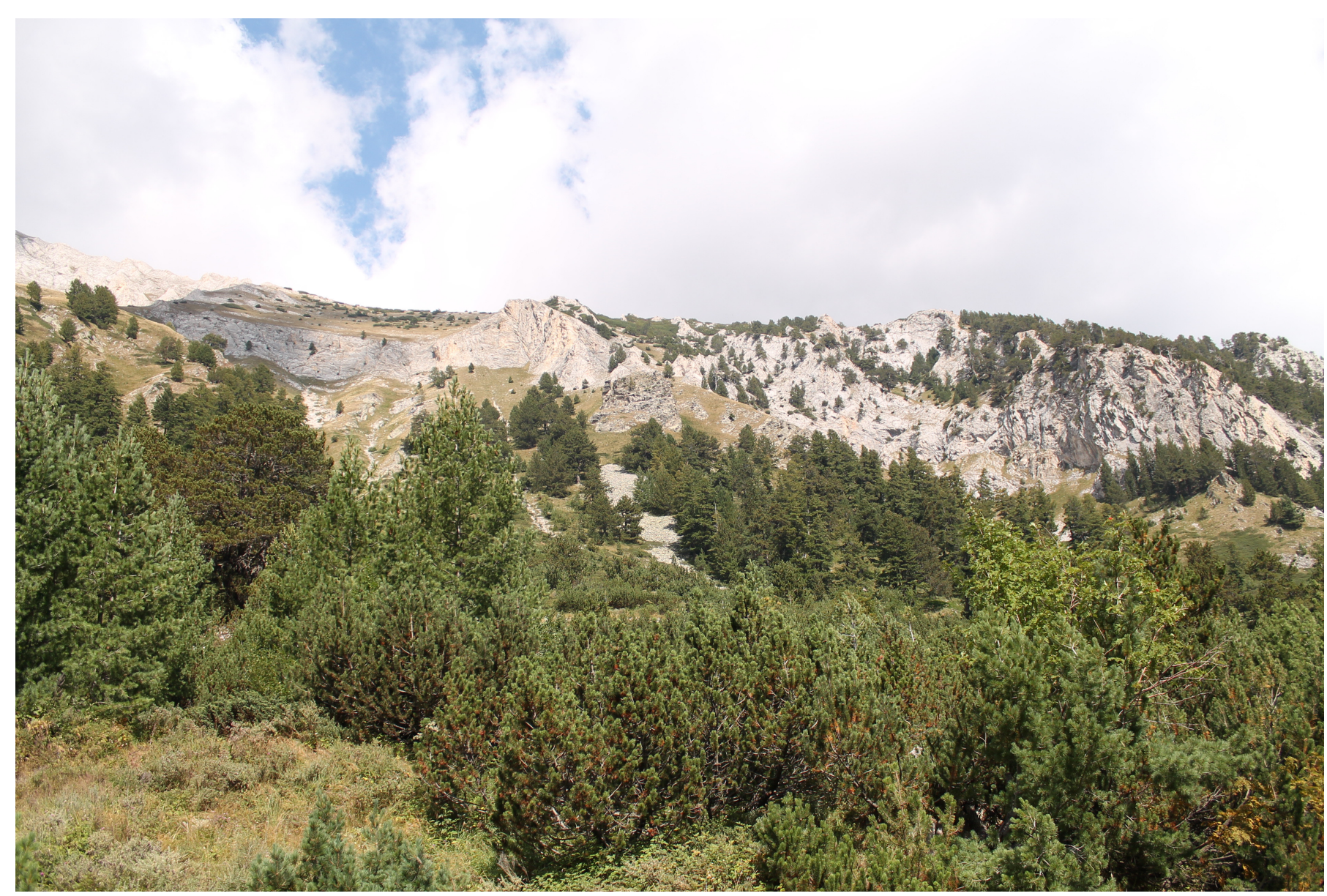

Fig. 5. High-mountain calcareous terrain with Pinus heldreichii in Pirin Mountain.

Table 2. Biological spectrum of calciphile dendroflora of Bulgaria according to Raunkiaer (1934)

\begin{tabular}{|c|c|c|c|}
\hline Life forms & facultative & obligate & Total \\
\hline $\mathrm{Ph}$ & 57 & 15 & 72 \\
\hline $\mathrm{Ch}$ & 6 & 7 & 13 \\
\hline $\mathrm{H}-\mathrm{Ch}$ & 4 & 5 & 9 \\
\hline $\mathrm{Ch}-\mathrm{Ph}$ & 6 & 1 & 7 \\
\hline $\mathrm{Ch}-\mathrm{H}$ & 4 & 2 & 6 \\
\hline Total & 77 & 30 & 107 \\
\hline
\end{tabular}

Depending on the vertical distribution in the country, plant species living within the altitudinal belt from 0 to $600 \mathrm{~m}$ above sea level are predominate (19 species), followed by the altitudinal belt $600-1000 \mathrm{~m}$ a.s.1. -18 species, $1000-1500 \mathrm{~m}$ a.s.1. -15 species, $1500-2000 \mathrm{~m}$ a.s.1. -13 species, 2000-2500 $\mathrm{m}$ a.s.1. -8 species. Only four species occur within the altitudinal belt from 2500 to 2900 $\mathrm{m}$ a.s.l. Fig. 3 (brown line) represents the vertical distribution of the obligate calciphile arboreal plants along altitudinal belts. The empirical relationship is $\mathbf{y}=\mathbf{- 3 . 0 5 7 1 x}+\mathbf{2 3 . 5 3 3}$, where $\mathbf{y}$ is the number of species, and $\mathbf{x}$ is the altitudinal belt. The regression coefficient is $\mathbf{R}^{\mathbf{2}}=\mathbf{0 . 9 5 7 4}$.

Amongst the 20 floristic regions of Bulgaria, the highest number of obligate calciphile species occurs in the Rhodopes (18 species $-62.1 \%$ of total number of obligate calciphile species in Bulgaria's dendroflora), followed by Stara Planina Mt. (Balkan Range) (Fig. 1) and Pirin Mt. with 15 species (51.7\%) (Fig. 5.) each; 12 species $(41.4 \%)$ are known from Slavyanka Mt., Vitosha region - 10 species, North-Eastern Bulgaria, Fore-Balkan, Znepole region, Thracian Plain -9 species each, Rila Mt. -8 species, the Tundzha Hilly Plain -7 species, the Black Sea coast and Sredna Gora Mt. - 6 species each, the Danubian Plain and West Frontier Mountains - 5 species each.

The group of obligate calciphiles in the Bulgarian dendroflora also has a large significance for nature conservation. The Red Data Book of the Republic of Bulgaria (Peev, 2015) contains data about 7 (24.1\% of the total number of obligate calciphile species in the Bulgarian dendroflora) of the investigated species: Aesculus hippocastanum, Caragana frutex, Convolvulus boissieri, Daphne laureola, Ruta graveolens, Thymus perinicus and Viola delphinantha. Eight species $(27.6 \%)$ are protected by the Biological Diversity Act (2007): Aesculus hippocastanum, Caragana frutex, Convolvulus boissieri, Daphne laureola, Iberis saxatilis, Ruta graveolens, Thymus perinicus and Viola delphinantha. Two species are included in the List of Rare Threatened and Endemic Plants in Europe (Lucas, 1983): Hyssopus officinalis and Viola 
delphinantha. Two species are listed in «1997 IUCN Red Lists of Threatened Plants» (Walter \& Gillett, 1998): Thymus perinicus and Viola delphinantha. Viola delphinantha is strongly protected by the Bern Convention (1978). Amongst the obligate calciphiles, there are five tertiary relics, 21 ornamental plants, 19 melliferous plants and six medicinal plants.

The presented data show that the calciphile Bulgarian dendroflora includes more than a quarter of the entire Bulgarian dendroflora. Species of the families Fabaceae, Rosaceae and of the genera Chamaecytisus, Genista and Rosa predominate. Shrubs predominate amongst the biological types, and phanerophytes are presented by the highest number of species amongst life form groups.

The geo-elements of the flora are represented mostly by stationary thermophilous species of Mediterranean origin that occur primarily in the lowest altitudinal belt. Pronounced linear relationship exists between the amount of calciphile plants in different vertical belts. Amongst the Bulgarian floristic regions, the majority of calciphile plants is known from the Rhodopes, Stara Planina Mt. (Balkan Range) and Pirin Mt., 19 calciphile species are known in all floristic regions, and 9 species - only in one certain floristic region.

The calciphile dendroflora has significant importance for nature conservation not only for Bulgaria but also for Europe as a whole. Being included in all analysed lists, Viola delphinantha is the most valuable species; it has a very high conservation value. The studied groups of plants include many tertiary relicts, endemics, ornamental, melliferous and medicinal plants.

\section{References}

Assyov B., Petrova A. (eds.). 2012. Conspectus of the Bulgarian Vascular Flora. Distribution Maps and Floristic Elements. Ed. 4. Sofia: Bulgarian Biodiversity Foundation. 490 p. [In Bulgarian].

Bern Convention. 1979. Convention on the Conservation of European Wildlife and Natural Habitats. Appendix I. http://www.bfn.de/0302 berner+M52087573ab0.html (Accessed 06.10.2016).

Biological Diversity Act (Act on Amending and Supplementing). 2007. Decree No 354 accepted by the 40th National Assembly on 1st November 2007. State Gazette: 94: 2-44. [In Bulgarian]

Bondev I. 1966. Map of floristic regions of Bulgaria. In: D. Jordanov (ed.): Flora of the PR Bulgaria. Vol. III. Sofia: Publ. House of BAS. 638 p.

Ellenberg H. 1974. Zeigerwerte der Gefässpflanzen Mitteleuropas. Scripta Geobotanica. Band 9. Gцttingen: Erich Golze. 97 p.

Georgiev A., Mihailov M. 1977. Afforestation of karst terrains. Sofia: Zemizdat. 106 p. [In Bulgarian]

Delipavlov D., Cheshmedzhiev I. (eds.). 2011. Guide to plants in Bulgaria. Plovdiv: Acad. Publ. House of Agr. Univ. 591 p. [In Bulgarian]
Jordanov D. (ed.). 1963. Flora of the People's Republic of Bulgaria. Vol. 1. Sofia: Bulgarian Academy of Sciences. 508 p. [In Bulgarian]

Jordanov D. (ed.). 1964. Flora of the People's Republic of Bulgaria. Vol. 2. Sofia: Bulgarian Academy of Sciences. 424 p. [In Bulgarian]

Jordanov D. (ed.). 1966. Flora of the People's Republic of Bulgaria. Vol. 3. Sofia: Bulgarian Academy of Sciences. 635 p. [In Bulgarian]

Jordanov D. (ed.). 1970. Flora of the People's Republic of Bulgaria. Vol. 4. Sofia: Bulgarian Academy of Sciences. 748 p. [In Bulgarian]

Jordanov D. (ed.). 1973. Flora of the People's Republic of Bulgaria. Vol. 5. Sofia: Bulgarian Academy of Sciences. 442 p. [In Bulgarian]

Jordanov D. (ed.). 1976. Flora of the People's Republic of Bulgaria. Vol. 6. Sofia: Bulgarian Academy of Sciences. 596 p. [In Bulgarian]

Jordanov D. (ed.). 1979. Flora of the People's Republic of Bulgaria.Vol. 7. Sofia: Bulgarian Academy of Sciences. 529 p. [In Bulgarian]

Kalinkov V., Pavlov D. Tashev A. 1991. Floristic studies in reserve «Sokolna». Nauka za Gorata 2: 3-9. [In Bulgarian]

Kozhuharov S. (ed.). 1995. Flora of the Republic of Bulgaria. Vol. 10. Sofia: Bulgarian Academy of Science. 431 p. [In Bulgarian].

Kozhuharov S., Anchev M. (eds.). 2012. Flora of the Republic of Bulgaria. Vol. 11. Sofia: Bulgarian Academy of Science. 527 p. [In Bulgarian].

Lucas G. 1983. List of Rare Threatened and Endemic Plants in Europe. Strasburg. 358 p.

Peev D. (ed.). 2015. Red Data Book of the Republic of Bulgaria. Vol. 1. Plants and Fungi. Sofia: IBEI - BAS \& MOEW. 848 p. [In Bulgarian]

Raunkiaer C. 1934. The life forms of plant and statistical plant geography. Oxford: Clarendon Press. 632 p.

Stefanoff B. 1943. Phytogeographical Elements in Bulgaria, Sofia: Bulgarian Academy of Science, Knipergraf. 509 p. [In Bulgarian]

Tashev A., Borisova D. 2005. Floristic inventory in the «Vrachansky Balkan» Nature Park. Forestry Ideas 2: 14-31. [In Bulgarian]

Tashev A., Angelova K. 2006. Floristic Investigations in Mount Chepan (Western Balkan Range). Silva Balcanica 7 (1): 95-102.

Tashev A., Alexandrova A. 2009. Systematic Structure and Floristic Elements of Sinite Kamani Natural Park (Eastern Stara Planina). Forestry Ideas 37: 105-113. [In Bulgarian]

Tashev A.N., Tsavkov E.I., Koev K.C. 2013a. Systematic structure and biological characteristics of the dendroflora in the biosphere reserve «Tchervenata stena» (Central Rhodopes, Bulgaria). In.: Kordum E.L. (ed.): Proceedings of International conference of young scientists «Advances in botahy and ecology». Ukraine, Shcholkine. P. 345-346.

Tashev A.N., Tsavkov E.I., Koev K.C. 2013b. Composition of floristic elements and conservation significance of the dendroflora in the biosphere reserve «Tchervenata stena» (Central Rhodopes, Bulgaria). In.: Kordum E.L. (ed.): Proceedings of International conference of young scientists "Advances in botany and ecology». Ukraine, Shcholkine. P. 346-348.

Tashev A.N., Koev K.S., Tashev N.A. 2013a. Systematic structure and biological characteristics of the flora in the Maintained Reserve «Izgorialoto Gyune» (Central Rhodopes, 
Bulgaria). In.: Ezhov V.N. (ed.): Proceedings of International conference «40 Years Natural Reserve "Cape Martyan"». Ukraine, Jalta. P. 103.

Tashev A.N., Koev K.S., Tashev N.A. 2013b. Composicion of floristic elements and conservational significance of the flora in the Maintained Reserve «Izgorialoto Gyune» (Central Rhodopes, Bulgaria). In.: Ezhov V.N. (ed.): Proceedings of International conference «40 Years Natural Reserve “Cape Martyan"”. Ukraine, Jalta. P. 102.

Velchev V. (ed.). 1982. Flora of the People's Republic of Bulgaria. Vol. 8. Sofia: Bulgarian Academy of Sciences. 518 p. [In Bulgarian]
Velchev V. 1989. Flora of the People's Republic of Bulgaria. Vol. 9. Sofia: Bulgarian Academy of Sciences. 539 p. [In Bulgarian]

Velchev V. 1998. Floral and plant biodiversity on calcareous terrains in Bulgaria. Phytologia Balcanica 4 (1-2): 8192. [In Bulgarian]

Walter K.S, Gillett H.J. (eds). 1998. 1997 IUCN Red List of Threatened Plants / Compiled by the World Conservation Monitoring Centre. IUCN - The World Conservation Union. Gland: Switzerland and Cambridge, UK. 862 p.

Uzunov D., Gussev Ch. 2003. High mountain flora of Bulgaria - Statistics, ecological characteristics and phytogeography. Bocconea 16 (2): 763-770.

\title{
ДЕНДРОФЛОРА КАРСТОВЫХ ТЕРРИТОРИЙ БОЛГАРИИ И ЕЕ КОНСЕРВАЦИОННОЕ ЗНАЧЕНИЕ
}

\author{
А. Н. Ташев, Е. И. Цавков \\ Лесотехнический университет, Болгария \\ e-mail: atashev@mail.bg,tsavkov@abv.bg
}

\begin{abstract}
В работе представлена характеристика кальцифильных видов дендрофлоры Болгарии (107 видов), как факультативных (77 видов), так и облигатных (30 видов) - их систематическая структура по семействам и родам, распределение по биологическим типам, жизненным формам, по геоэлементам флоры, а также распространение по вертикальным поясам и флористическим районам Болгарии. Показана консервационная значимость кальцифилов на националном и международном уровне на основе референтных документов. Представлен полный систематический список кальцифильных видов дендрофлоры Болгарии.
\end{abstract}

Ключевые слова: Болгария, дендрофлора, карстовые территории, консервационная значимость. 